33. Nordstrom, D. K. and Southam, G., Geomicrobiology-interactions between microbes and minerals. Mineral Soc. Am., 1997, 35, 261-390.

34. Rose, A. W. and Cravotta, C. A., Geochemistry of coal mine drainage, Coal Mine Drainage Prediction and Pollution Prevention in Pennsylvania, Pennsylvania Department of Environmental Protection, PA 17101, 1998

35. Asta, M. P., Cama, J., Soler, J. M., Arvidson, R. S. and Luttge, A., Interferometric study of pyrite surface reactivity in acidic conditions. Am. Mineral., 2008, 93, 508-519.

ACKNOWLEDGEMENTS. I acknowledges technical support of Central Institute of Mining and Fuel Research, Horticulture Department and Directorate of Mineral Resources, Government of Meghalaya, North Eastern Hill University and Director, NERIWALM (Assam) of India for conducting the study.

\title{
Diversity and conservation status of mangrove communities in two areas of Mesocaribea biogeographic region
}

\author{
Ana Cano Ortiz ${ }^{1}$, Carmelo M. Musarella ${ }^{1,2}$, \\ José C. Piñar Fuentes ${ }^{1}$, Carlos J. Pinto Gomes ${ }^{3}$, \\ Sara Del Río González ${ }^{4}$ and Eusebio Cano ${ }^{1, *}$ \\ ${ }^{1}$ Department of Animal and Plant Biology and Ecology, \\ Botany Section, Universidad de Jaén, Campus Universitario \\ Las Lagunillas, Spain \\ ${ }^{2}$ Department of AGRARIA, 'Mediterranea' \\ University of Reggio Calabria, Italy \\ ${ }^{3}$ Department of Landscape, Environment and Planning/Institute of \\ Agricultural and Environmental Sciences, Mediterranean, \\ University of Évora, Rua Romão Ramalho, Portugal \\ ${ }^{4}$ Department of Biodiversity and Environmental Management (Botany), \\ Faculty of Biological and Environmental Sciences, University of León \\ Spain
}

The study of mangrove communities (Avicennia germinans, Conocarpus erectus, Laguncularia racemosa and Rhyzophora mangle) in Central America reveals a total diversity of 121 species included in 7 plant communities, of which 15 are characteristic of mangroves and 31 of flooded areas with less pronounced salinity, while 75 are invasive species belonging to neighbouring communities. Frequent fires in the dry forest have caused intense erosion, leading to the silting of the lake basin. As a result, the first belt of Rhizophora vegetation is extremely rare. In contrast, there is a predominance of Laguncularia and Conocarpus mangrove plants, in addition to a belt of Phragmito Mag-

\footnotetext{
*For correspondence. (e-mail: ecano@ujaen.es)
}

nocaricetea with a high incidence of Phragmites australis, which acts as an indicator of sediment silting due to its shallowness.

Keywords: Biogeographic region, diversity and conservation, mangroves, phytosociology.

MANGROVE communities grow in tropical and subtropical areas between parallel $30^{\circ} \mathrm{N}$ and $30^{\circ} \mathrm{S}$ on different continents ${ }^{1-8}$. Mangroves are important for their role in estuarine ecological systems and shoreline protection ${ }^{9-12}$. They provide fish breeding-grounds and act as barriers to erosion and habitat for wildlife ${ }^{13-15}$. However, exploitation of mangroves can affect biodiversity and ecosystem services ${ }^{16,17}$. Mendes and Tsai ${ }^{18}$ studied of mangrove swamp sediments in transect from the outermost to the innermost areas of a mangrove swamp in Southeastern Brazil. They sampled three points consisting of the species Laguncularia racemosa, Avicennia shaueriana and Rhizophora mangle, and analysed a variety of physical and chemical parameters that condition the microbial biogeochemistry of the soil. They highlighted the need to preserve mangrove areas from degradation. Studied on the degradation of non-mangrove forests in protected areas (PAs) ${ }^{19,20}$ in Latin America revealed that they increased from $0.04 \%$ to $0.10 \%$ between 2004 and 2009 , with a considerable rise in area (ha) altered by serious erosion and the resulting sediment deposit ${ }^{19,20}$. This degradation is caused by the density of the rural population and its proximity to the habitat, and to the decline in funding for PAs, however, it is somewhat offset by protection measures in these threatened areas. We recently highlighted the need to establish conservation measures for two American mangrove forests ${ }^{4}$, as they are facing a variety of threats ${ }^{21}$. One of these is particularly the high rate of sediment deposit caused by deforestation of peripheral areas, which is silting mangrove forests, as in the case of several mangrove swamps in Mexico (Laguna de Tres Palos, Acapulco, and Guerrero). The Rhizophora sp. habitat is being substituted by that of $L$. racemosa, whose habitat is in turn substituted by Conocarpus erectus, owing to reduction in depth of the lake basin, an increased inflow of freshwater, and a decrease in salinity. This horizontal dynamics is accompanied by an increase in the area occupied by Phragmites australis and Typha domingensis ${ }^{22,23}$, species whose optimal development occurs in sites with shallow standing water and low salinity, in contrast to the requirements for mangroves. Typical mangrove species are therefore being replaced by others from outside this type of community. Mangrove communities should therefore be regarded as fragile, as they require a specific depth of water and salinity. Another threat to the mangrove habitat is deforestation by the rural community for use as an energy source. This could be reduced if the per capita income of the population were higher, which would allow them access to other energy sources ${ }^{24,25}$. 
This combination of factors leads to a shrinking of the areas occupied by these ecosystems, which are of paramount ecological value as they are the home to other species of interest such as the hawksbill sea turtle. This was highlighted in the 2012 Inter-American Convention for the protection and conservation of sea turtles, which analysed the state of conservation of this species and its use of habitats in the eastern Pacific Ocean. The analysis established that adult hawksbill sea turtles use estuaries with mangroves as their main foraging habitat; this is also the case in the areas we have studied on the Pacific coast of Mexico. The intense human pressure on the mangrove habitat $^{26,27}$ is clearly sufficient grounds for our proposal to measure the diversity and verify the state of conservation of these communities, as outlined in the Mexican CONABIO regulations ${ }^{28}$. The diversity measurement records the abundance of all the species in each community/association to assess their state of conservation. This method considers the conservation of each community, and allows the implementation of new management practices. In view of the above, the aim of this study is to determine the degree of floristic diversity and the state of conservation of mangrove habitats.

We have studied the diversity and state of conservation of mangrove forests by analysing 70 field phytosociological samples of vegetation from two areas of Mesocaribea biogeographic region (Mexico and Dominican Republic), with a total area of $95,300 \mathrm{~m}^{2}$ sampled and an average coverage of $92 \%$, following the methodology reported by Braun-Blanquet ${ }^{29}$. This methodology consists in assessing a list of plant species present in an area and attributing to each of them a plus sign or a number from 1 to 5. This index denotes the proportion of the area covered by that species (cover abundance), according to these values: from + (sparse species and covering a small area) to 5 (abundant species covering more than $75 \%$ of the area). We call 'relevé' the plants list complete of their indices of cover-abundance and other ecological parameters collected in the field. The 70 relevés are grouped by ecological, physiognomic and floristic affinities into seven plant communities, based on the physiognomic affinities of the dominant species $(\mathrm{Ma}-\mathrm{Rh}=$ Machario lunati Rhizophoretum manglis Cano et al. 2012, Rh-La= Rhabdadenio biflori-Laguncularietum racemosae Cano et al. 2012, St-La=Sthalio monospermae-Laguncularietum racemosae Cano et al. 2012, Lo-Co = Lonchocarpo pycnifolli Conocarpetum erecti Cano et al. 2012, Lo-La = Lonchocarpo sericei-Laguncularietum racemosae Cano et al. 2012, $\mathrm{Cr}-\mathrm{Co}=$ Crataevo tapiaeConocarpetum erectae Cano et al. 2012 and $\mathrm{Ro}-\mathrm{Pt}=$ Roistoneo hispaniolanae-Pterocarpetum officinalis Cano et al. 2009).

Each plant community has a particular floristic composition. We assign a cover-abundance index to each spe$\operatorname{cies}^{29}$, whose values are $+, 1,2,3,4$ and 5. For statistical analysis, these indices are transformed into discrete numerical Van der Maarel indices ${ }^{30}$ with the following equivalence: $r,+=2,1=3,2=4,3=5,4=6$ and $5=7$. This transformation is required as the cover-abundance values are non-numerical, making it impossible to use numerical analyses. PCA analysis was done to see the grouping of the relevés. Once the affinity relations were established between the different associations, we applied Spearman's correlation coefficient $\left(r_{\mathrm{s}}\right)$ as the data did not follow a normal distribution, and because this correlation coefficient is more robust for values that fall far short of expectations, and for discrete cover-abundance values. Shannon's index was used to measure diversity, and applied to all the species in each community (Shannon-t), the characteristic species (Shannon-c), the invasive plants (Shannon-in) and species in transition (Shannon-tr). The statistical packages CAP (Community Analysis Package III), Past and XLSTAT-2009 were used. We assessed the state of conservation with a comparative analysis of the number and abundance of the typical, invasive and transitional mangrove species using the cover-abundance indices for the relevés collected in the Dominican Republic and Mexico (Acapulco) ${ }^{4}$. We established the mean values of the cover-abundance indices of 70 relevés $\left(V_{\mathrm{mc}}=\right.$ mean characteristic values, $V_{\mathrm{mt}}=$ mean transitional values, $V_{\min }=$ mean invasive values) and performed a linear regression analysis to determine the relation between $V_{\mathrm{mc}}$ and $V_{\mathrm{mt}}+V_{\mathrm{min}}$. Three groups (A-C) were formed with the species in the sampling according to the ecological niche to which they belong, and a comparative analysis of the species diversity and abundance was done. If all the species in the community/association were typical or characteristic, the degree of conservation was estimated to be maximum; its theoretical value can be as high as 7 , as this is the maximum value in the Van der Maarel coverabundance index. Shannon's index was used to measure diversity, and applied to all the species in each community, characteristic species, invasive plants and transitional species. These are species that live in humid environments that are temporarily or permanently waterlogged and have high salinity (mangrove forest plants), in environments in which the salinity ranges from $0.2 \%$ to $1.3 \%$, according to Mendes and Tsai ${ }^{18}$. Other species live in humid or temporarily waterlogged environments, with or without slight salinity (species in transition between the mangrove forest and neighbouring communities), in this case the salinity gradient is less than $0.2 \%$. These species inhabit places waterlogged with freshwater, as in the case of Gran Estero in the Dominican Republic ${ }^{31}$. Invasive species from nearby communities typical of dry environments are those from communities in the surroundings, essentially belonging to dry forest ${ }^{32}$. For the seven communities studied, we established the difference between the mean values of the abundance indices for the characteristic species in the association and higher syntaxonomic units, and the mean values of the companion species represented by groups $\mathrm{B}$ and $\mathrm{C}$ (transitional and inva- 
sive). Once the three groups of species were established in each of the seven associations, we applied Shannon's index to each of them, considering the total species, the characteristic species in each association and higher syntaxonomic units, the species in waterlogged places but without salinity - and in which there are therefore no transitional species - and finally, the invasive species that enter the mangrove forest due to silting of the lake basin. This provides information on the diversity in each sample and each plant association.

PCA ordination analysis separates the relevés of Ro-Pt from the rest, which is to be expected as the former belong to the forest growing in swamp areas in Gran Estero. These zones differ from mangrove areas as they are prone to flooding with freshwater, and therefore, there is a high floristic difference between Ro-Pt and the rest of the mangrove associations. The species in this Ro-Pt association belong to group B, i.e. in transition between the characteristic mangrove species and those belonging to communities from dry environments in the surroundings (Figure 1).

Spearman's correlation matrix using the species coverabundance values highlights the excellent negative correlations between the association $\mathrm{Ro}-\mathrm{Pt}$ and those of Lo-Co, Lo-La and Ma-Rh, owing to the antagonism of this association with all the others. The $P$ value is $<0.05$, revealing a highly significant level of correlation (Table 1).

In a comparative analysis of the diversity between plant associations, the intrinsic diversity of each community - or alpha diversity - for each association is highest in Rh-La, with Shannon-c $=1.790$, and lowest in Ro-Pt, with Shannon-c $=0$. The rate of change in community species - or beta diversity - is highest in Ro-Pt, with Shannon in $+\operatorname{tr}=3.455$, and lowest in Ma-Rh, with Shannon in $+\operatorname{tr}=0$. It is also interesting to note that in the association $\mathrm{Ma}-\mathrm{Rh}$, the values for Shannon-t and Shannon-c (1.369) are the same, with a value of 0 in the case of transitional (group B) and invasive species (group C), showing the null diversity of introgressive species. In this situation, $\mathrm{Ma}-\mathrm{Rh}$ can be considered to have a good state of conservation despite its low diversity. To determine the state of conservation of the seven plant communities/associations, we calculated the mean values of the abundance/dominance indices for each relevé and community in terms of their characteristic $\left(V_{\mathrm{mc}}\right)$, transitional $\left(V_{\mathrm{mt}}\right)$ and invasive $\left(V_{\min }\right)$ species, according to Cano et al. ${ }^{33}$. This analysis grouped the values $V_{\mathrm{mt}}+V_{\min }$ together to determine the progression of species belonging to other aquatic communities and from dry environments that were found in the studied communities. Taking into account the values of the species, transitional and invasive characteristics, we observed in relevés $V_{\mathrm{mt}}+V_{\min }=0$ that when the value of $V_{\mathrm{mc}}>0$, if $V_{\mathrm{mt}}+V_{\min }>0$, there are two outcomes: this value is either lower or higher than $V_{\text {mc }}$. This can be explained by a change in the biotope due to the decrease in salinity and silting, leading to the entry of species from groups B and C. If $V_{\mathrm{mt}}+V_{\mathrm{min}}>V_{\mathrm{mc}}$, the degree of conservation of the mangrove community declines. The regression analysis between $V_{\mathrm{mc}}$ and $V_{\mathrm{mt}}+V_{\mathrm{min}}$ is perfectly correlated, with a degree of goodness $R^{2}=0.961$ (Figure 2). All the associations have a level of threat of $V_{\mathrm{mc}}<7$ due to changes in the biotope, and this is maximum in the zones occupied by Ro-Pt, whose $V_{\mathrm{mc}}=1$.

According to the criteria established in Rodríguez et $a l{ }^{34}$ for threat-level categories, with the exception of the association Ro-Pt, the six remaining associations studied - whose $V_{\mathrm{mc}}$ value ranges between 4 and 4.83 - have a threat level between endangered (EN) and vulnerable (VU). However, we consider Ro-Pt, with $V_{\mathrm{mc}}=1$ and $V_{\mathrm{mt}}+V_{\min }=7$, to be a plant community that has replaced the former mangrove forests. The mangrove has thus been eliminated (EL) in this area because of the drastic modification of the biotope (Table 2).

The greatest differences occur between the Mexican mangrove communities Lo-La and $\mathrm{Cr}-\mathrm{Co}$ and those in the Dominican Republic, and between the Ro-Pt communities and the rest of the associations. Mangrove communities are an imperilled biome whose protection and restoration can contribute to improved livelihoods, climate mitigation and adaptation ${ }^{35-37}$. The high floristic diversity found in some mangrove communities is not synonymous with a good state of conservation. Quite the reverse: this floristic diversity is a cause for alarm, as it is due to the high number of invasive species that are difficult to eradicate, while current threats are maintained in the form of cutting, burning, forest fires, charcoal manufacture and others. The high number of invasive species causes a deterioration of the mangroves. The analysis shows that the relevés of Ro-Pt have a high species diversity, but no diversity in the presence of mangrove species. Ro-Pt is particularly noteworthy in the comparison between the seven communities. Ellison and Farnsworth $^{38}$ labelled several classes of anthropogenic disturbances in Caribbean mangrove swamps: extraction of commercial wood, which in the present case occurs in some of the plots sampled in the Dominican Republic, the impact of fishing - due to infrastructures - in addition to the impact on fishing itself, as the modification of mangrove habitat affects fish diversity, and pollution from petroleum and other pollutants such as heavy metals ${ }^{39}$, pesticides and municipal waste - this has a decisive influence on the mangrove swamp in Samaná Bay (Gran Estero). Other disturbances include an ill-conceived and highly contaminating and degrading type of tourism which alters the mangrove ecosystems, and mass deforestation of neighbouring habitats which leads to erosion and sediment deposit in the lake basin, and allows the entry of invasive species that are not characteristic of the mangrove swamp. The increase of the infrastructures aggravates the destruction of the mangroves because they occupy their natural sites ${ }^{40}$. According to Díaz Gaxiola ${ }^{21}$, 


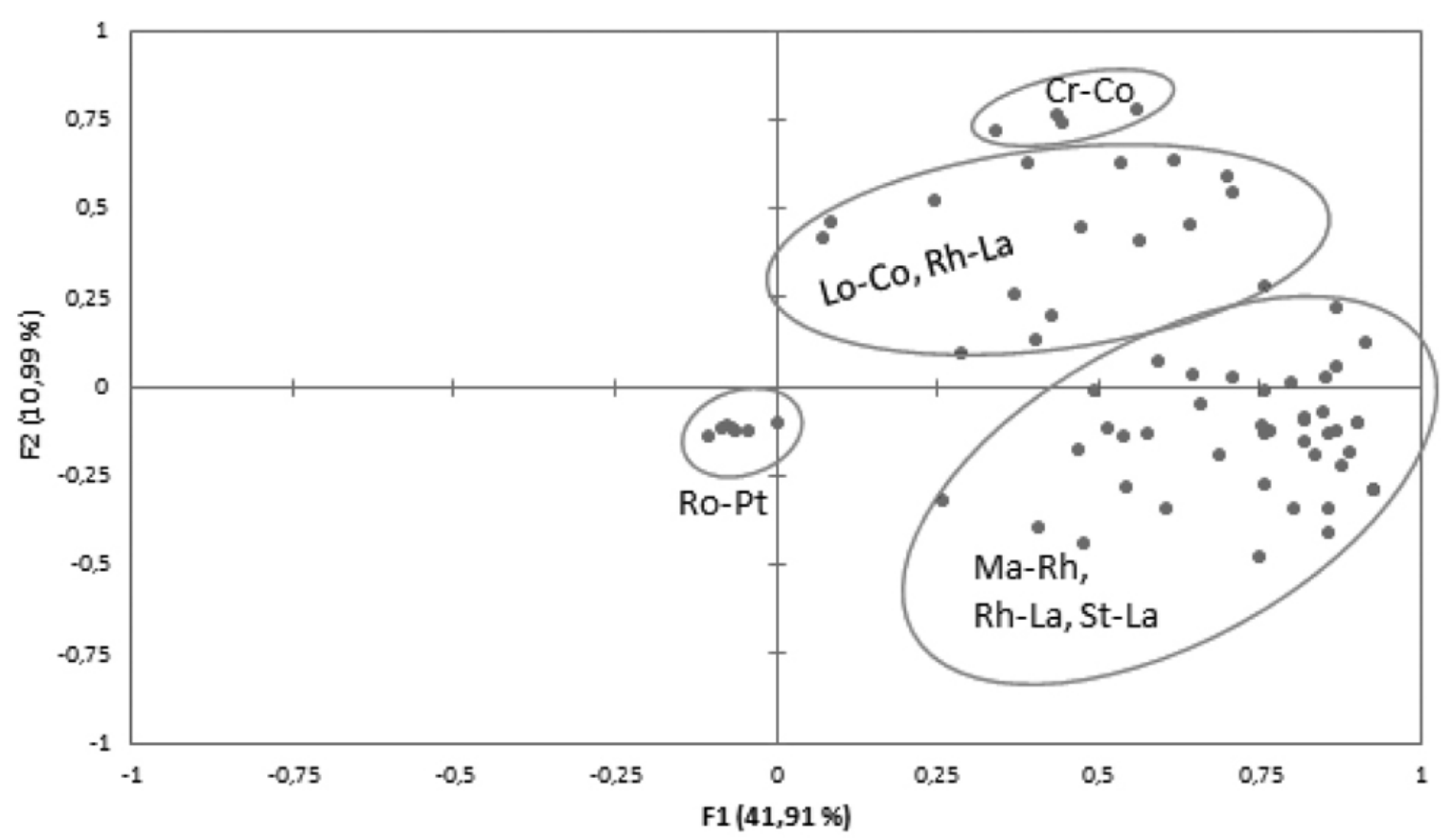

Figure 1. Principal component analysis ordination analysis with separation between the mangrove relevés and Ro-Pt relevés not belonging to the mangrove forest.

Table 1. Correlation matrix (Spearman)

\begin{tabular}{lccccccc}
\hline Variables & Cr-Co & Lo-Co & Lo-La & Ma-Rh & Rh-La & Ro-Pt & St-La \\
\hline Cr-Co & $\mathbf{1}$ & $\mathbf{0 . 3 4 2}$ & $\mathbf{0 . 4 9 3}$ & $\mathbf{0 . 6 6 2}$ & $\mathbf{0 . 4 7 9}$ & -0.127 & $\mathbf{0 . 3 1 2}$ \\
Lo-Co & $\mathbf{0 . 3 4 2}$ & $\mathbf{1}$ & 0.166 & $\mathbf{0 . 4 4 7}$ & $\mathbf{0 . 3 1 7}$ & $-\mathbf{0 . 3 3 1}$ & $\mathbf{0 . 3 5 6}$ \\
Lo-La & $\mathbf{0 . 4 9 3}$ & 0.166 & $\mathbf{1}$ & $\mathbf{0 . 3 7 5}$ & $\mathbf{0 . 2 2 1}$ & $\mathbf{- 0 . 2 2 8}$ & $\mathbf{0 . 1 8 1}$ \\
Ma-Rh & $\mathbf{0 . 6 6 2}$ & $\mathbf{0 . 4 4 7}$ & $\mathbf{0 . 3 7 5}$ & $\mathbf{1}$ & $\mathbf{0 . 5 0 2}$ & $\mathbf{- 0 . 1 8 1}$ & $\mathbf{0 . 5 0 0}$ \\
Rh-La & $\mathbf{0 . 4 7 9}$ & $\mathbf{0 . 3 1 7}$ & $\mathbf{0 . 2 2 1}$ & $\mathbf{0 . 5 0 2}$ & $\mathbf{1}$ & -0.055 & $\mathbf{0 . 3 3 1}$ \\
Ro-Pt & -0.127 & $-\mathbf{0 . 3 3 1}$ & $\mathbf{- 0 . 2 2 8}$ & $\mathbf{- 0 . 1 8 1}$ & -0.055 & $\mathbf{1}$ & -0.164 \\
St-La & $\mathbf{0 . 3 1 2}$ & $\mathbf{0 . 3 5 6}$ & $\mathbf{0 . 1 8 1}$ & $\mathbf{0 . 5 0 0}$ & $\mathbf{0 . 3 3 1}$ & -0.164 & $\mathbf{1}$ \\
\hline
\end{tabular}

Values in bold are different from 0 with a level of significance of alpha $=0.05$.

mangrove forests grow at the limits of the continents and in ocean waters, and are inhabited by a wide variety of wild flora and fauna. They are a source of food (fish, crustaceans and others), and an important habitat for the hawksbill sea turtle; this is the case of both the mangrove swamps of Laguna de Tres Palos and Laguna Benítez de Coyuca (Mexico), and a range of sampled locations in the Dominican Republic (Laguna de Oviedo, Bahía de Niebla, Cabo Rojo, Pedernales). Forest resources (timber, firewood and charcoal) are overexploited by local populations as a source of energy, although in other locations they are used to extract tannins and honey. Additionally, mangrove swamps act as bioremediation for marine pollution $^{41}$, and play an important role in primary and secondary productivity in coastal waters ${ }^{42}$. A range of other causes leading to the deterioration of the mangrove swamps have been analysed, including hotel construction and the opening of roads to provide access to beaches ${ }^{43,44}$.
Tourism is among the factors with the most destructive effect on the habitat, as in the case of the Dominican Republic (Bahía de Niebla, Barahona, Majagua-Punta Arena, Yeguada River estuary, Mitches, Camino al Cayo Limón) $)^{45}$.

The present study highlights this trend and the state of conservation of the 70 plots in the sampling. The best conserved mangrove communities are therefore those which have only typical mangrove species and no companions, even in the case of monospecific populations of Rhizophora, Laguncularia, Avicennia and Conocarpus. The mangrove forest should be regarded as a fragile ecosystem as it is demanding too in its ecological conditions in terms of water depth, salinity and specific substrate. This means that any alteration triggers and substitution of these communities by neighboring ones. The maximum total diversity corresponds to $\mathrm{Ro}-\mathrm{Pt}=3.485$, but its alpha diversity is zero as it has no typical mangrove species. 


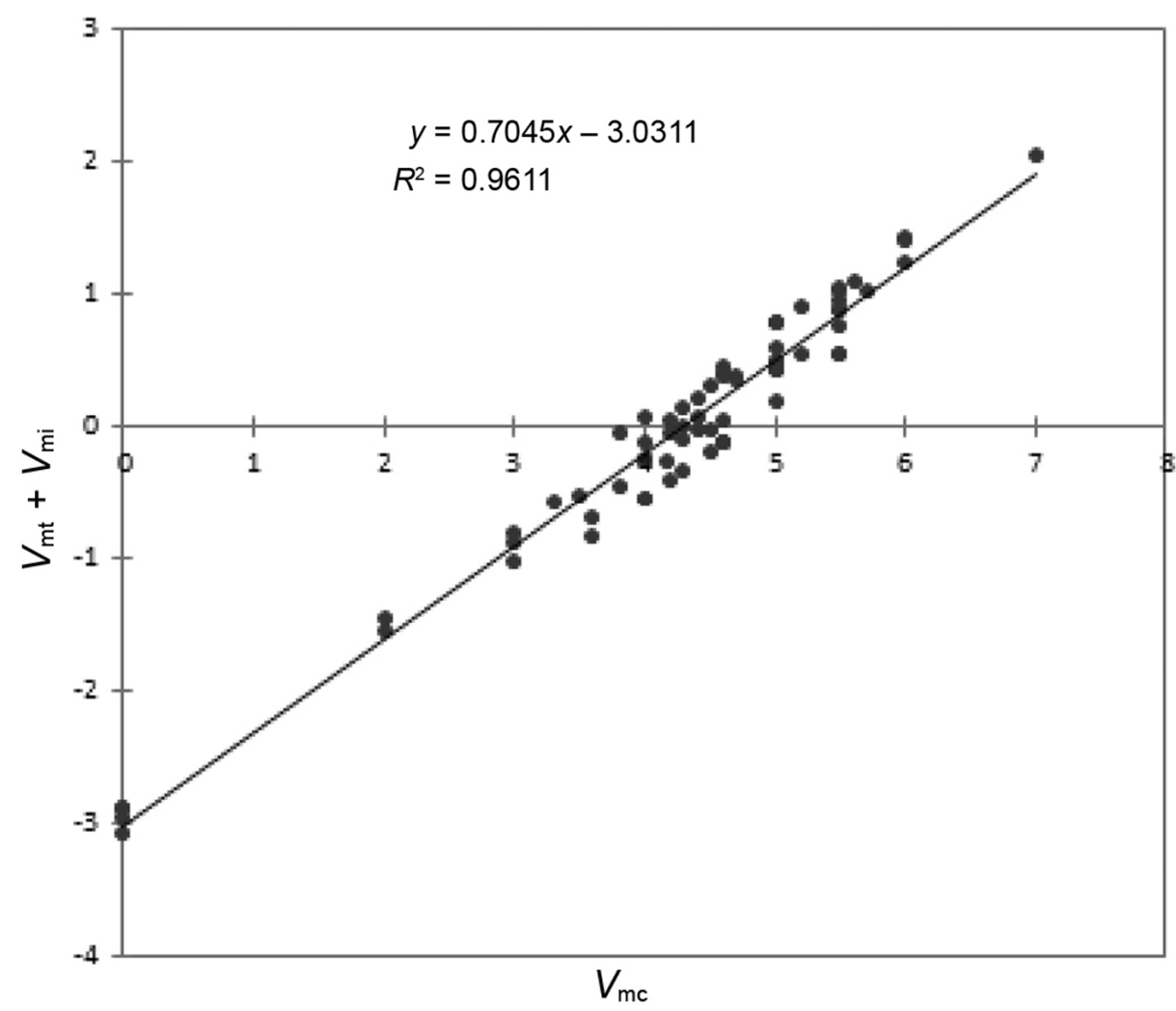

Figure 2. Regression analysis between $V_{\mathrm{mc}}$ and $V_{\mathrm{mt}}+V_{\min }$.

Table 2. $V_{\mathrm{mc}}, V_{\mathrm{mt}}$ and $V_{\mathrm{min}}$ of the seven associations

\begin{tabular}{llllcccc}
\hline Variables & $V_{\mathrm{mc}}$ & $V_{\mathrm{mt}}$ & $V_{\min }$ & $V_{\mathrm{mt}}+V_{\min }$ & $V_{\mathrm{mc}}-V_{\mathrm{mt}}$ & $V_{\mathrm{mc}}-V_{\min }$ & $V_{\mathrm{mc}}-\left(V_{\mathrm{mt}}+V_{\min }\right)$ \\
\hline Cr-Co & 4.5 & 0.8 & 1.6 & 2.4 & 3.7 & 2.9 & 2.1 \\
Lo-Co & 4 & 1.5 & 1.8 & 3.3 & 2.5 & 2.2 & 0.7 \\
Lo-La & 4.67 & 1.4 & 1.3 & 2.7 & 3.27 & 3.37 & 1.97 \\
Ma-Rh & 4.67 & 1.9 & 1.4 & 3.3 & 2.77 & 3.27 & 1.37 \\
Rh-La & 4.83 & 1.8 & 1.4 & 3.2 & 3.03 & 3.43 & 1.63 \\
Ro-Pt & 1 & 4 & 3 & 7 & -3 & -2 & -6 \\
St-La & 5 & 2.6 & 1.8 & 4.4 & 2.4 & 3.2 & 0.6 \\
\hline
\end{tabular}

The maximum alpha diversity corresponds to $\mathrm{Rh}-\mathrm{La}$, with Shannon-c $=1.790$, but with a high beta diversity of Shannon-in $+\operatorname{tr}=2.089$. As the beta diversity is higher than the alpha diversity, $\mathrm{Rh}-\mathrm{La}$ may be endangered. In contrast, Ma-Rh has an alpha diversity of 1.369 and a beta diversity of zero, and its state of conservation is therefore high. In terms of this relationship, $\mathrm{Cr}-\mathrm{Co}$ has Shannon-c value $=1.092$ and Shannon-in $+\operatorname{tr}=0.636$, as Shannon-tr and Shannon-in have a value of zero in the relevés. It is worth noting the existence of three samples, viz. Ma-Rh25, Ma-Rh29 and Ma-Rh54 which have a Shannon value of zero for their characteristic species (Shannon-c =0). This is the case of Ro-Pt, in which all the relevés have a Shannon-c value $=0$. This is explained by the absence of any typical or characteristic mangrove species. By applying Shannon index to the mean cover- abundance values in each species for each community (Cr-Co, Lo-Co, Lo-La, Ma-Rh, Rh-La, Ro-Pt, St-La), we obtained the Shannon diversity values for the total species found in the community (Shannon-t), the characteristic species (Shannon-c), transitional species (Shannontr) and invasive species (Shannon-in). The relationship between alpha diversity and beta diversity only shows that the associations $\mathrm{Cr}-\mathrm{Co}$ and $\mathrm{Ma}-\mathrm{Rh}$ have alpha diversity higher than beta diversity; in other associations, the opposite occurs (Table 3), revealing a trend towards a change in diversity due to alterations in the biotope caused by threats. The extreme case is Ro-Pt with a high total diversity, which does not correspond to the mangroves.

Ro-Pt has the maximum total diversity in the seven communities studied, although its alpha diversity is zero 


\section{RESEARCH COMMUNICATIONS}

Table 3. Shannon diversity values for each association (all species, characteristic, transitional, invasive and invasive + transitional)

\begin{tabular}{llllclll}
\hline Diversity index & Cr-Co & Lo-Co & Lo-La & Ma-Rh & Rh-La & Ro-Pt & St-La \\
\hline Shannon-t & 1.486 & 3.14 & 2.428 & 1.369 & 2.622 & 3.485 & 2.835 \\
Shannon-c & 1.092 & 1.749 & 1.419 & 1.369 & 1.79 & 0 & 1.691 \\
Shannon-tr & 0.6365 & 1.772 & 1.069 & 0 & 1.762 & 1.522 & 0.9243 \\
Shannon-in & 0 & 2.692 & 1.934 & 0 & 0 & 3.289 & 2.495 \\
Shannon-in + tr & 0.6365 & 3.196 & 2.259 & 0 & 2.089 & 3.455 & 2.863 \\
\hline
\end{tabular}

as it has no typical mangrove species. The maximum alpha diversity corresponds to $\mathrm{Rh}-\mathrm{La}$, with Shannon-c = 1.790 , but with a high beta diversity (Shannon-in $+\operatorname{tr}=$ 2.089) due to transformations in the biotope. As the beta diversity is higher than the alpha diversity, $\mathrm{Rh}-$ La may be endangered. In contrast, $\mathrm{Ma}-\mathrm{Rh}$ has an alpha diversity of 1.369 and a beta diversity of zero, revealing a good state of conservation. This method confirms that phytosociological studies can be applied to determine the state of conservation of plant associations by conducting a comparative analysis of the diversity of species that are statistically faithful to the community/association - and thus characteristic - and the companion species (transgressive and invasive), thus establishing the trend for a specific community. In some of the sampling plots, the silting process is transforming the plant communities of Rhizophora, Laguncularia and Avicennia into Conocarpus communities. In the case of excessive silting and decrease in salinity of the lake basin, the mangroves give way to other communities, as found in Gran Estero, where the forest has been substituted by $P$. officinalis. It must be accepted that the mangrove forest has disappeared in Gran Estero due to the silting of the lake basin and freshwater input, that has resulted in the replacement of the mangrove habitat by Ro-Pt forest. It is therefore necessary to recommend a management plan for this type of habitat. Carmona-Díaz et al. ${ }^{46}$ proposed a management plan for mangroves swamps in Veracruz, Mexico which in its general outlines can be applied to any other site. This plan considers several fundamental areas such as research (interaction with biotic and abiotic elements, structure and dynamics, in addition to the traditional use of resources and ecotourism), education (design and application of environmental education programmes, among others) and conservation (indicator species and biological processes). As the problems affecting mangroves swamps-such as deforestation, contaminated waste, species invasion, agricultural and tourist-related activities, etc. - are similar throughout the world, these activities should be regulated to ensure the sustainable use of the territory. In conclusion, a high Shannon diversity value does not imply that a community is well conserved; the degree of conservation depends not on the total diversity, but on the relationship between intrinsic diversity (alpha diversity) and beta diversity. Communities with the highest $V_{\mathrm{mc}}$ values are the best conserved.
Based on these results, we propose concrete measures to mitigate and prevent the destruction of mangroves communities: (i) ban on deforestation in peripheral areas to avoid erosive phenomena and the consequent filling of the lagoon vessel. (ii) Ban on deforestation for energy extraction. (iii) Implementation of policies for the integration of rural populations in their environment. (iv) Control of mass tourism.

1. Alvarado, H., Silva, R., Soriano, P., Alonso, M. A. and Costa, M., Comunidades vegetales de arenales, manglares y saladares costeros Del sur-este Del estado de Falcón (Venezuela). In Bioclima Mediterráneo y Vegetación (eds Gallardo, A. J. et al.), Alicante, España, 2009.

2. Álvarez, V. and Bonnelly de Calvente, I., Los manglares Del sur y su conservación. In Conservación y Desarrollo Volumen 1 (eds Bonnelly CIBIMA/UASD), Santo Domingo, República Dominicana, 1978, pp. 149-192.

3. Borhidi, A., Phytogeography and vegetation ecology of Cuba, Editorial Académiai Kiado, Budapest, Hungary, 1991.

4. Cano, E., Cano-Ortiz, A., Veloz, A., Alatorre, J. and Otero, R., Comparative analysis between the mangrove swamps of the Caribbean and those of the State of Guerrero (Mexico). Plant Biosyst. (Suppl.), 2012, 146, 112-130.

5. Kjerfve, B., De Lacerda, L. D. and Diop, E. H. S. (eds), Mangrove Ecosystem Studies in Latin America and Africa, UNESCO, Paris, France, 1997.

6. Reyes, O. J. and Acosta Cantillo, F., Fitocenosis presentes las áreas costeras del sur de la Sierra Maestra, Cuba I, Comunidades con influencia marina. For. Veracruzana, 2003, 5(2), 1-8.

7. Singh, V. P., Garge, A., Pathak, S. M. and Mall, L. P., Mangrove forests of Andaman Islands in relation to human interference. Environ. Conserv., 2009, 13(2), 169-172.

8. Suman, D. O. (ed.)., El ecosistema de manglar en America Latina y la cuenca del Caribe: su manejo y conservación, Rosenstiel School of Marine and Atmospheric Science (Universidad de Miami) \& The Tinker Foundation, editors, New York, 1994, p. 255.

9. Rode, J., Wittmer, H., Emerton, L. and Schröter Schlaack, C., Ecosystem service opportunities: a practice-oriented framework for identifying economic instruments to enhance biodiversity and human livelihoods. J. Nat. Conserv., 2016, 33, 35-47.

10. Sandilyan, S. and Kathiresan, K., Mangrove conservation: a global perspective. Biodivers. Conserv., 2012, 21, 3523.

11. Teas, H. J., Ecology and restoration of mangrove shorelines in Florida. Environ. Conserv., 2009, 4(1), 51-58.

12. Villalobos Zapata, G. J., Yáñez Arancibia, A., Day Jr, J. W. and Lara Domínguez, A. L., Ecología y manejo de los manglares en la Laguna de Términos, Campeche, México, 1999, pp. 263-274; In A. Yáñez Arancibia y A. L. Lara Domínguez (eds), Ecosistemas de Manglar en América Tropical. Instituto de Ecología A.C. México, UICN/ORMA, Costa Rica, NOAA/NMFS Silver Spring MD USA, 1999, p. 380. 
13. Bijleveld, M., Importance and status of mangroves. Environ. Conserv., 2009, 8(4), 284.

14. Rönnbäck, P., Troell, M., Zetterström, T. and Babu, D. E., Mangrove dependence and socio-economic concerns in shrimp hatcheries of Andhra Pradesh, India. Environ. Conserv., 2003, 30(4), 344-352.

15. Walton, M. E. M., Samonte Tan, G. P. B., Primavera, J. H., Edwards-Jones, G. and Le Vay, L., Are mangroves worth replanting? The direct economic benefits of a community-based reforestation project. Environ. Conserv., 2006, 33(4), 335-343.

16. Malik, A., Fensholt, R. and Mertz, O., Mangrove exploitation effects on biodiversity and ecosystem services. Biodivers. Conserv., 2015, 24, 3543.

17. Calderón, C., Aburto, O. and Ezcurra, E., El valor de los mamglares. Biodiversitas, 2009, 82, 1-6.

18. Mendes, L. W. and Tsai, S. M., Variations of bacterial community and composition in mangrove sediment at different depths in Southeastern Brazil. Diversity, 2014, 6, 825-843.

19. Leisher, C., Touval, J., Hess, S. M., Boucher, T. M. and Reymondin, L., Land and forest degradation inside protected areas in Latin America. Diversity, 2013, 5(4), 779-795.

20. Nunes, S. S., Barlow, J., Gardner, T. A., Siqueira. J. V., Sales, M. R., Carlos, M. and Souza, J. R., A 22 years' assessment of deforestation and restoration in riparian forests in the eastern Brazilian Amazon. Environ. Conserv., 2015, 42(3), 193-203.

21. Díaz Gaxiola, J. M., Una revisión sobre los manglares: características, problemáticas y su marco jurídico. importancia de los manglares, el daño de los efectos antropogénicos y su marco jurídico: caso sistema lagunar de Topolobampo. Ra Ximhai, 2011, 7(3), 355-369.

22. Escutia-Lara, Y. and Lindig-Cisneros, R., Dinámica de Phragmites australis y Schoenoplectus americanus en respuesta a la adición de fósforo y nitrógeno en humedales experimentales. Bot. Sci., 2012, 90(4), 459-467.

23. García Fuentes, A., Castillo Cabrera, F. J., Dávila Pérez, C. V., Morales, A. S., Salazar, C., Lendinez, M. L. and Torres, J. A., La Vegetación de la reserva de usos multiples de Monterrico (Guatemala). In Servicio de Publicaciones de la Universidad de Castilla La Mancha, Avances en el conocimiento de la vegetación, Toledo, España, 2012, p. 31

24. Rodríguez-Zúñiga, M. T. et al., Manglares de México/Extensión, distribución y monitoreo. CoNABIO, 2013, p. 128.

25. Norma Oficial Mexicana NOM-059-ECOL-2001, Protección ambiental-Especies nativas de México de flora y fauna silvestresCategorías de riesgo y especificaciones para su inclusión, exclusión o cambio-Lista de especies en riesgo, 2002, UNINET.

26. Lizano, O. G., Amador, J. and Soto, R., Caracterización de manglares de Centroamérica con sensores remotos. Rev. Biol. Trop. (Suppl. 2), 2001, 49, 331-340.

27. Uribe Pérez, J. and Urrego Giraldo, L. E., Environmental management of mangrove ecosystems. Gest. Ambiente, 12, 2, 57-72.

28. Vázquez-Lule, A. D., Rodríguez-Zúñiga, M. T. and RamírezGarcia, P., Caracterización del sitio de manglar Sistema Lagunar de Alvarado Veracruz, Comisión Nacional para el Conocimiento y USO De La Biodiversidad, Sitios de manglar con relevancia biológica y con necesidades de rehabilitación ecológica, CONABIO, México D.F., 2009.

29. Braun-Blanquet, J., Fitosociología. Bases para el estudio de las comunidades vegetales, Editorial Blume, Madrid, España, 1979 , p. 820 .

30. Van der Maarel, E., Transformation of cover-abundance values in phytosociology and its effects on community similarity. Vegetatio, 1979, 39, 97-114.

31. Cano, E., Veloz, A., Cano-Ortiz, A. and Esteban, F. J., Analysis of the Pterocarpus officinalis forests in the Gran Estero (Dominican Republic). Acta Bot. Gallica, 2009, 156(4), 559-570.
32. Cano Ortiz, A., Musarella, C. M., Piñar, J. C., Spampinato, G., Veloz, A. and Cano, E., Vegetation of the dry bioclimatic areas in the Dominican Republic. Plant Biosyst., 2015, 149(3-4), 451472.

33. Cano, E., García, A., Nieto, J. and Torres, J. A., Estudio de la evaluación de hábitats de Laguna Honda (Jaén, España). I Coloquio Internacional de ecología da vegetaçao, Departamento de Ecologia da Universidade de Evora, editor, Evora, Portugal, 1996.

34. Rodríguez, J. P. et al. (eds), Libro rojo de los ecosistemas terrestres de Venezuela, 1st edition, La Galaxia, Venezuela, 2010.

35. Warren Rhodes, K. et al., Mangrove ecosystem services and the potential for carbon revenue programmes in Solomon Islands. Environ. Conserv., 2011, 38(4), 485-496.

36. Yáñez Arancibia, A., Twilley, R. R. and Lara Dominguez, A. L., Los ecosistemas de manglar frente al cambio climático global. Madera Bosques, 1998, 4, 2, 3-19.

37. Yáñez Arancibia, A., Day, J. W., Twilley, R. R. and Day, R. H., Mangla-res; ecosistema centinela frente al cambio climático, Golfo de México. Madera y Bosques, 2014, 20(3), 39-75.

38. Ellison, A. M. and Farnsworth, E. J., Anthropogenic disturbance of Caribbean mangrove ecosystems: past impacts, presents trends and future predictions. Biotropica, 1996, 28(4), 549-565.

39. Olguín, E. J., Hernández, M. E. and Sánchez-Galván, G., Contaminación de manglares por hidrocarburos y estrategias de biorremediación, fitorremediación y restauración. Rev. Int. Contam. Ambient, 2007, 23(3), 139-154.

40. Ahmed, S. E., Ewers, R. M. and Matthew, J. S., Large scale spatio-temporal patterns of road development in the Amazon rainforest. Environ. Conserv., 2014, 41(3), 253-264.

41. Foroughbakhch, R., Céspedes, A., Alvarado, M., Núñez, A. and Bahi, M., Aspectos ecológicos de los manglares y su potencial como fitorremediadores en el Golfo de México. Cienc. UANL, 2004, 7(2), 1-6.

42. INE, Evaluación preliminar de las tasas de pérdida de superficie de manglar en México, Ed. Semanart, 2005, p. 21.

43. Hirales Cota, M., Espinoza Avalos, J., Schmook, B., Ruiz Luna, A. and Ramos Reyes, R., Drivers of mangrove deforestation in Mahahual Xcalak, Quintana Roo, southeast México. Cienc. Mar., 2010, 36(2), 147-159.

44. Yañez-Arancibia, A. and Lara-Domínguez, A. L., Los manglares de América Latina en la encrucijada, 1999, pp. 9-16; In A. Yáñez-Arancibia y A.L. Lara Domínquez (eds.). Ecosistemas de Manglar en América Tropical. Instituto de Ecología A.C. México, UICN/ORMA, Costa Rica, NOAA/NM, FS Silver Spring MD, USA, 1999, p. 380.

45. Flores Mejía, M. A., Aguirrer Vallejo, A., Flores Hernández, M. and Guardado Govea, X., El impacto que produce el sector turismo en los manglares de las costas mexicanas. Contacto $S, 2010$, 77, 33-38.

46. Carmona Díaz, G., Morales Mávil, J. E., Rodríguez Luna, E., Plan de manejo para el manglar de Sontecomapan, Catemaco, Veracruz, México: una estrategia para la conservación de sus recursosnaturales. Madera y Bosques, 2004, 2, 5-23.

ACKNOWLEDGEMENT. We thank Ms Pru Brooke Turner (MA Cantab.) for English translation of this article.

Received 30 January 2018; revised accepted 3 April 2018

doi: $10.18520 / \mathrm{cs} / \mathrm{v} 115 / \mathrm{i} 3 / 534-540$ 